\title{
KILAT
}

Vol. 9, No. 1, April 2020, P-ISSN 2089-1245, E-ISSN 2655-4925

DOI: https://doi.org/10.33322/kilat.v9i1.786

\section{PLN Organizational Leaders Manajemen Talent sebagai Strategi Pengelolaan Human Capital}

\author{
Musthofa \\ UPDL Pandaan, PLN Pusdiklat, Indonesia \\ musthofa6623@gmail.com
}

\begin{abstract}
The high demands of customers on the reliability of the quality of electric power to the government's efforts to meet electricity needs through the 35,000 MW Program pose a serious challenge to PLN. The crucial condition of the distribution section is the spearhead of PLN in preparing leaders who understand culture and business challenges. PLN has not used a character approach to place employees according to the Type of Position that has different job demands and characters. The problems faced by PLN in implementing talent management, the difficulty in determining talent in the right position (the right man in the right place) with the target of preparing future leaders $25 \%$ of the total 49,100 employees to PLN as an Orgazational Leader. The PESTEL Analysis method that considers strategic issues and critical success factors (CSF) generated Talent Profile Data with personality preferences measured by MBTI and DISC test kits. The purpose of this study is to create a Business Unit Character Profile and Talent Personality Profile. The results of the study formed the personal character of talent 140 employees or $68 \%$ of the talent pool, Character Model Work units have been classified from external challenges in the work unit and issued a decree mutation promotion of top supervisors and basic managers 33 people who went up and 48 people up the level of the organization. Impacted performance improvement PLN East Java Distribution achieved the best performance (94.1) and NKO Value 95.0 in 2017.
\end{abstract}

Keywords: Personal character, Business unit character, Organizational leaders

\begin{abstract}
ABSTRAK
Tingginya tuntutan pelanggan terhadap keandalan kualitas tenaga listrik terhadap upaya pemerintah memenuhi kebutuhan listrik melalui Program 35.000 MW memberikan tantangan berat $P L N$. Kondisi krusial bagian distribusi sebagai ujung tombak PLN dalam mempersiapkan leader yang memahami cultural dan tantangan bisnis. PLN belum menggunakan pendekatan karakter untuk menempatkan pegawai sesuai Jenis Jabatan yang memiliki tuntutan dan karakter pekerjaan yang berbeda. Permasalahan yang dihadapi PLN dalam implementasi managemen talent, kesulitan menentukan talent dalam posisi yang tepat (the right man in the right place) dengan target mempersiapkan future leader 25\% dari total 49.100 pegawai menuju PLN sebagai Orgazational Leader. Metode Analisa PESTEL yang mempertimbangkan isu strategis dan critical suces factor (CSF) dihasilkan Data Talent Profile dengan preferensi kepribadian yang diukur dengan alat tes MBTI dan DISC. Tujuan penelitian ini membuat Profil Karakter Unit Bisnis dan Profil Kepribadian Talent. Hasil penelitian terbentuknya Karakter pribadi talent 140 pegawai atau sebesar $68 \%$ dari talent pool, Model Karakter Unit kerja sudah diklasifikasikan dari tantangan eksternal di unit kerja dan terbit SK mutasi promosi supervisor atas dan manajer dasar 33 orang yang naik jenjang dan 48 orang naik tingkat organisasi. Berdampak peningkatan kinerja PLN Distribusi Jawa Timur mencapai kinerja terbaik (94,1) dan Nilai NKO 95,0 pada tahun 2017.
\end{abstract}

Kata kunci: Karakter personal, Karakter unit bisnis, Orgazational leaders 


\section{PENDAHULUAN}

Tingginya tuntutan pelanggan terhadap keandalan kualitas dan pasokan tenaga listrik merupakan tantangan tersendiri bagi PLN untuk dapat merealisasikan komitmen Pemerintah dalam pembangunan penyediaan listrik sebesar 35.000 Megawatt (MW).

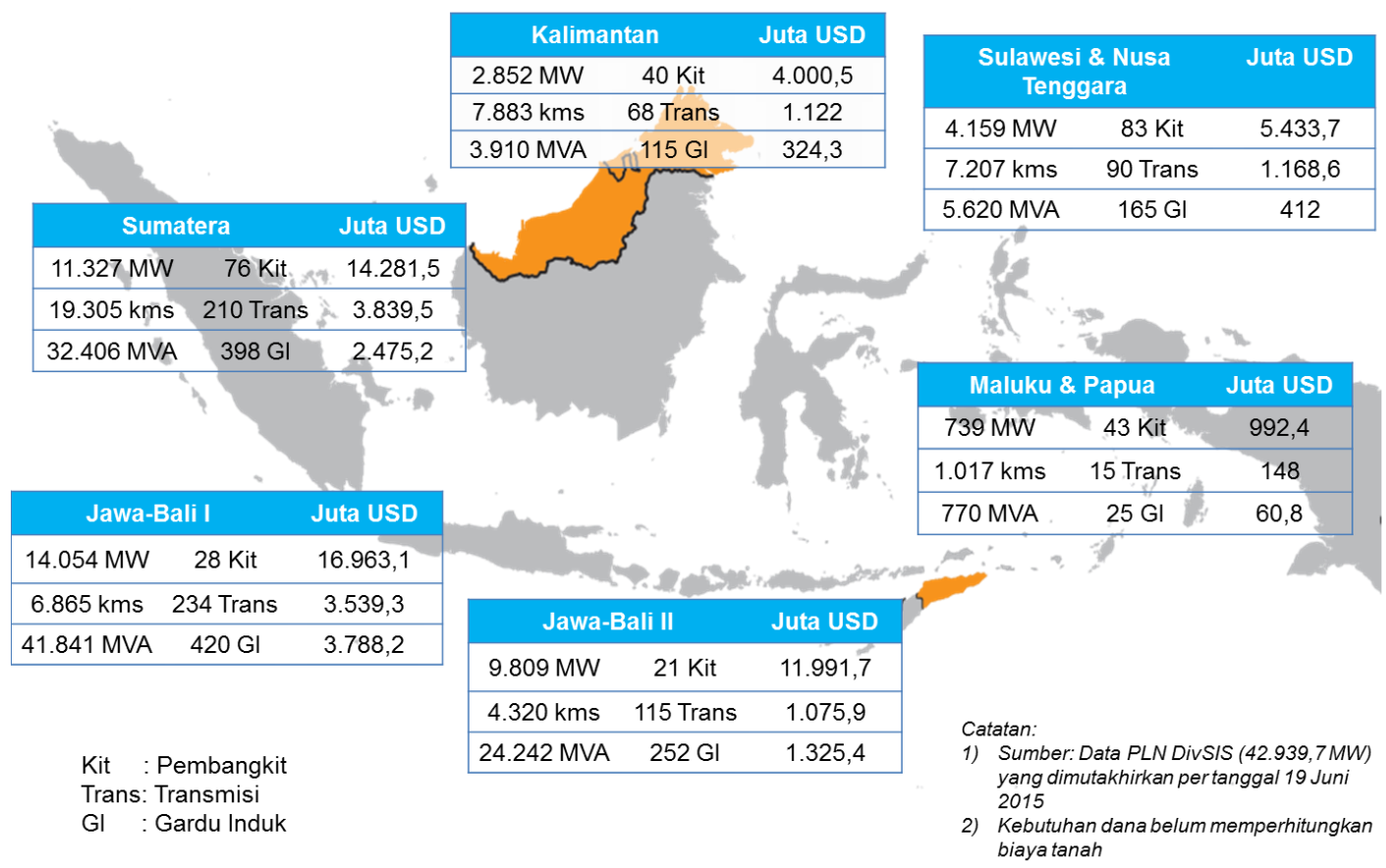

Gambar 1. Sebaran jumlah kapasitas dan kebutuhan dana pembangkit, Transmisi dan Gardu Induk Program $35.000 \mathrm{MW}[1]$

Kesuksesan Organisasi ditentukan oleh barisan Sumber Daya Manusia yang bertalenta tinggi. Great Organizations are always built by Great people.[2] Oleh karena itu, Sumberdaya manusia yang bertalenta menjadi keunggulan kompetitif utama dan menjadi aspek penting bagi perusahaan dalam menghadapi persaingan bisnis di era global yang menuntut daya adaptasi yang tepat dalam menghadapi berbagai perubahan yang turbulen dan kompleks.[3]

Komposisi Pejabat Struktrural saat ini dapat dilihat dalam grafik dibawah ini:

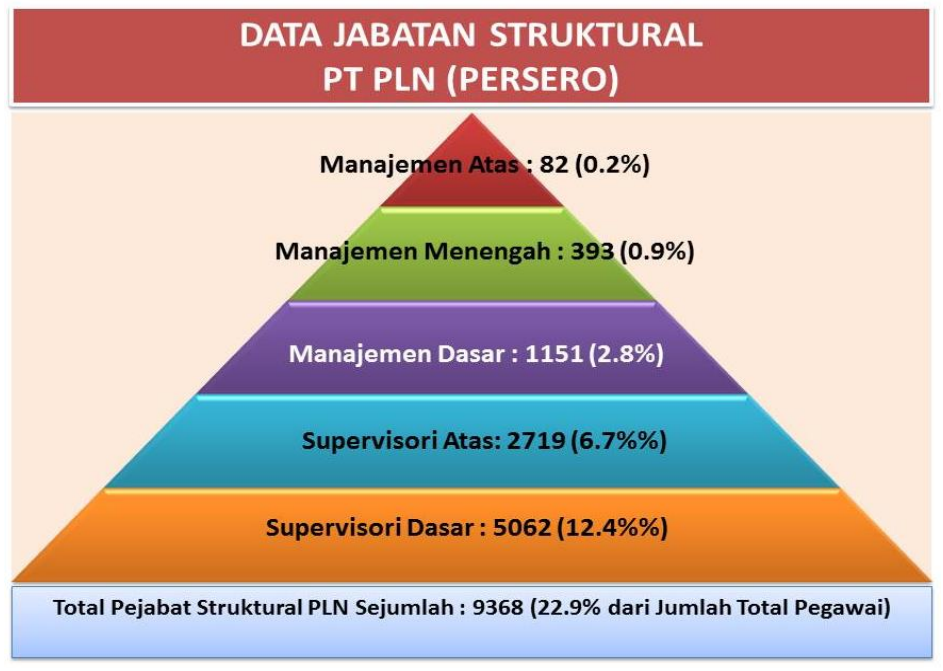

Gambar 2. Komposisi Pejabat Struktural PT PLN (Persero) [4] 


\section{KILAT}

Vol. 9, No. 1, April 2020, P-ISSN 2089-1245, E-ISSN 2655-4925

DOI: https://doi.org/10.33322/kilat.v9i1.786

Tabel 1. Pejabat Struktural (setelah reorganisasi) posisi Maret 2017

\begin{tabular}{lrc}
\multicolumn{1}{c}{ Jenjang } & Jumlah & Prosen \\
Manajemen Atas & 107 & $0,26 \%$ \\
Manajemen Menengah & 402 & $0,96 \%$ \\
Manajemen Dasar & 1.241 & $2,98 \%$ \\
Supervisor Atas & 2.858 & $6,85 \%$ \\
Supervisor Dasar & 5.795 & $13,89 \%$ \\
Fungsional 1 & 12 & $0,03 \%$ \\
Fungsional 2 & 75 & $0,18 \%$ \\
Fungsional 3 & 437 & $1,05 \%$ \\
Fungsional 4 & 2.964 & $7,11 \%$ \\
Fungsional 5 & 13.328 & $31,95 \%$ \\
Fungsional 6 & 14.491 & $34,74 \%$ \\
Jumlah PT PLN (Persero) & 41.710 & $100,00 \%$ \\
Anak Perusahaan & 7.390 & $15,05 \%$ \\
Total & 49.100 & $100,00 \%$ \\
\hline
\end{tabular}

Total Pejabat Struktural 10.403 atau $24,94 \%$ dari total pegawai 41.710

Dengan Jumlah pejabat structural sebanyak 10.403 atau sebanyak 24,94\% dengan berbagai fungsi dengan unit-unit kerja yang mempunyai keunikan masing-masing dan critical job yang berbeda-beda sehingga muncul kesulitan dalam menentukan the right man in the raight place untuk memperoleh produktifitas pegawai dan kinerja yang Dimana pada system talent pool yang ada saat ini (SK DIR 007) belum mempertimbangkan karakter personal, karakter unit kerja dan karakter jabatan dalam melakukan program pengembangan talent.

\subsection{Human Capital}

Kesuksesan Organisasi ditentukan oleh barisan Sumber Daya Manusia yang bertalenta tinggi. Great Organizations are always built by Great people. [2] Oleh karena itu, sumberdaya manusia yang bertalenta menjadi keunggulan kompetitif utama dan menjadi aspek penting bagi perusahaan dalam menghadapi persaingan bisnis di era global yang menuntut daya adaptasi yang tepat dalam menghadapi berbagai perubahan yang turbulen dan kompleks. Dengan demikian Manajemen Talent menjadi program unggulan perusahaan dalam rangka mencapai visi, misi, dan sasaran stratejik serta meningkatkan pertumbuhan dan keberlanjutan organisasi (growth and sustainability)[5].

\subsection{Talent Management}

Talent Management merupakan inti dari konsep Human Capital. Kesuksesan suatu perusahaan sangat ditentukan oleh Talent Management Strategy yang digunakan. ketika berbicara mengenai Talent Management Strategy, maka yang pertama kali harus dimiliki oleh perusahaan adalah gambaran kebutuhan talenta yang diperlukan. Pada umumnya perusahaan sudah menyadari kebutuhan talenta berdasarkan visi, misi, strategi, dan nilai perusahaan.[6] Namun ternyata perkiraan kebutuhan talent berdasarkan tantangan industri di masa mendatang sering dilupakan. Melalui penilaian ini, maka akan diketahui seberapa lengkap talent yang sudah dimiliki perusahaan dibandingkan dengan kebutuhannya, sehingga bisa dilakukan berbagai usaha untuk menutupi kesenjangan yang ada.[3]

\subsection{Implementasi MBTI dan Best Practise}

MBTI dikembangkan oleh Katherine Cook Briggs dan Isabel Briggs Myers pada awal tahun 1950an. MBTI didesain untuk membuat Teori Jung lebih explisit dan dapat diaplikasikan dalam 
kehidupan sehari-hari.[7] Pada tahun 2006 MBTI sudah diterjemahkan kedalam 21 bahasa Best Practise di dunia bisnis MBTI sudah banyak digunakan oleh perusahaan-perusahaan terkenal diantaranya McKinsey \& Company dan CIA, bahkan 80\% dari 100 perusahaan Fortune 500 dan 89 dari Perusahan Fortune 100 menggunakan MBTI untuk menempatkan karyawannya pada posisi yang tepat dan mendorong kesuksesan mereka (Taube, 2015), pada perusahaan Multinasional salah satunya adalah Pertamina.[8]

\section{Perumusan Manajemen Talent}

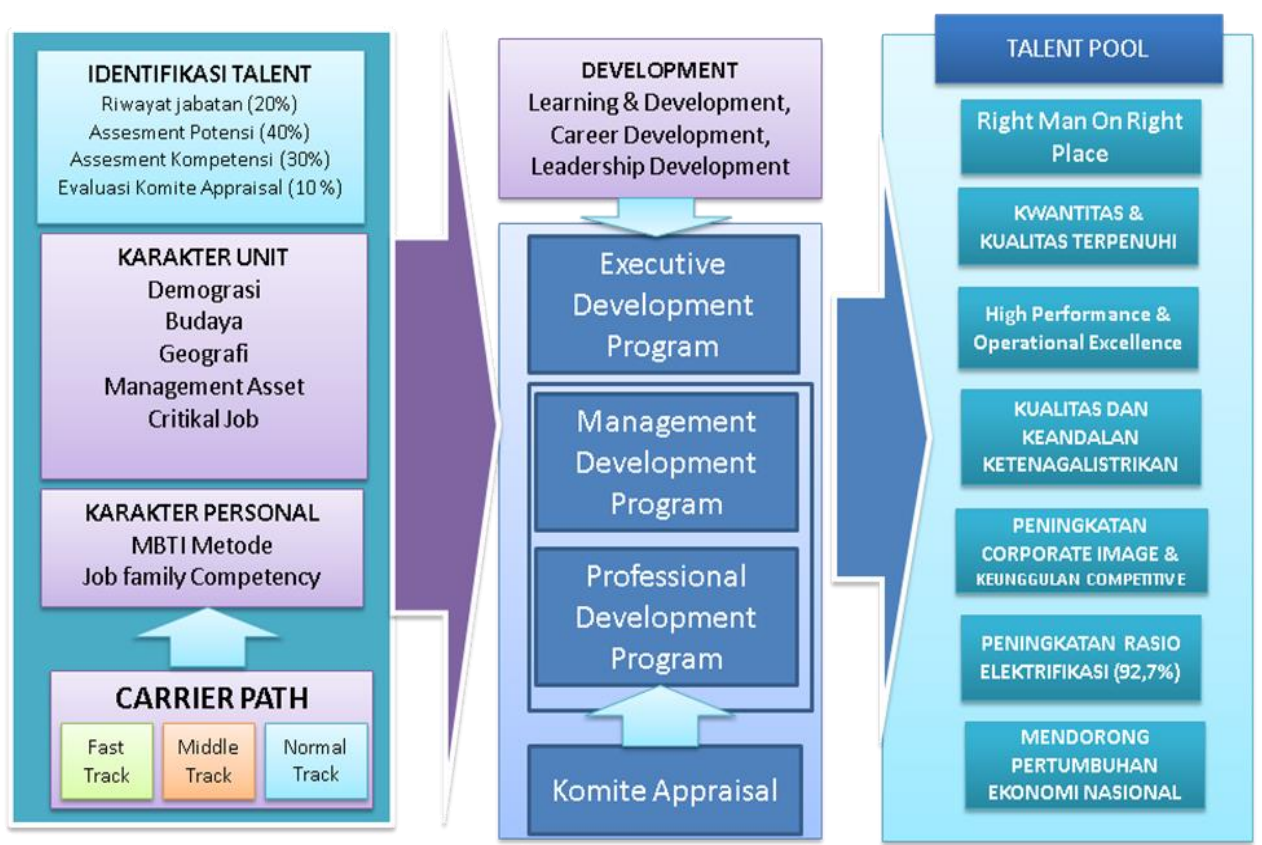

Gambar 3. Perumusan manajemen Talent [9]

\section{Metodologi}

Pendekatan yang digunakan oleh PT PLN (Persero) dalam pengisian jabatan saat ini dilakukan dengan mempertimbangkan kesesuaian kebutuhan kompetensi individu Pegawai (KI) dengan kebutuhan kompetensi jabatan (KKJ) yang diatur sesuai dengan Direktori Kompetensi PLN (Tahun 2017) dimana Standarisasi Kebutuhan Kompetensi didasarkan pada Jenjang Jabatan dan Kompetensi Teknis. PLN belum menggunakan pendekatan karakter untuk menempatkan pegawai sesuai dengan Jenis Jabatan yang memiliki tuntutan dan karakter pekerjaan yang berbeda. Permasalahan yang dihadapi saat ini dalam implementasi managemen talent, masih adanya kesulitan menentukan talent dalam posisi tepat (the right man in the right) [5]

Dalam pembahasan analisa masalah penulis menggunakan Analisa PESTEL (politik, ekonomi, Sosial, teknologi, lingkungan dan legal) dengan mempertimbangkan isu strategis dan menentukan critikal sucses factors (CSF).[10] 


\section{KILAT}

Vol. 9, No. 1, April 2020, P-ISSN 2089-1245, E-ISSN 2655-4925

DOI: https://doi.org/10.33322/kilat.v9i1.786

Tabel 2. Kerangka Analisa

\begin{tabular}{|c|c|c|c|c|c|c|c|c|}
\hline \multicolumn{9}{|c|}{ DRIVING FORCES } \\
\hline \multirow{2}{*}{ KEY DRIVER } & \multirow{2}{*}{ ISSUE STRATEGIC } & \multicolumn{3}{|c|}{ IMPACT } & \multicolumn{2}{|c|}{ PROBABILITY } & \multirow{2}{*}{$\begin{array}{l}\text { CRITICAL SUCCESS FACTORS } \\
\text { (CSF) }\end{array}$} & \multirow[t]{2}{*}{ AUDIT CSF } \\
\hline & & $\mathbf{L}$ & M & H & L $\quad M$ & $\mathrm{H}$ & & \\
\hline \multirow[t]{4}{*}{ Geopolitik } & 1. Penugasan Pemerintah $35000 \mathrm{MW} \& 42000 \mathrm{kms}$ & & & V & & $\mathrm{V}$ & Proses Pengadaan lahan dan Kesiapan SDM PLN & $\begin{array}{l}\text { Jumlah dan kompetensi SDM masih kurang } \\
\text { (banyak purnakarya) \& Rekrutmen Baru }\end{array}$ \\
\hline & 2. Rasio Elektrifikasi $94,7 \%$ pada tahun 2019 & & & V & & V & Insfrastruktur Cukup dan Kemampuan SDM PLN & $\begin{array}{l}\text { Kompetensi SDM perlu ditingkatkan dgn } \\
\text { program percepatan karier untuk critical job }\end{array}$ \\
\hline & 3. Kebijakan pemerintah utk IPP bangun $25000 \mathrm{MW}$ & & & V & & $\mathrm{v}$ & Kesiapan IPP & \\
\hline & 4. Adanya MEA & & V & & V & & Daya Saing SDM PLN & $\begin{array}{l}\text { Komptensi SDM ditingkatkan sesuai } \\
\text { Kompetensi global }\end{array}$ \\
\hline \multirow[t]{4}{*}{ Economic } & 1. Pertumbuhan GDP Global rata-rata $3 \%$ & & V & & V & & Regulasi Pemerintah untuk medorong Ekonomi & \\
\hline & 2. Growth Economic National rata-rata $4 \% \mathrm{sd} 6 \%$ & & & v & & v & Harus didukung Infrastrutur ketenagalistrikan & \\
\hline & 3. Pasar Bebas Ekonomi Asian (MEA) & & V & & & v & Competitive Advantege Produk dan tenaga kerja & $\begin{array}{l}\text { Program Pengembangan SDM berbasis Kinerja } \\
\text { dan spesialisasi }\end{array}$ \\
\hline & 4. Pendanaan program $35000 \mathrm{MW}$ dan $42000 \mathrm{kms}$ & & & V & V & & Kepastian Pendanaan dari Lender dan PMN & \\
\hline \multirow[t]{3}{*}{ Social } & 1. Ketersediaan pasar tenaga kerja & & & V & & v & Tersedia Talent yang mempunyai kompetensi & $\begin{array}{l}\text { Manajemen Talent perlu dikembangkan } \\
\text { dengan The Right Man the Right place }\end{array}$ \\
\hline & 2. Persaingan Tenaga kerja pada era MEA & & V & & & V & Manajemen HCM yang menarik Generasi Y & $\begin{array}{l}\text { Program Pengembangan Gen Y dan Personality } \\
\text { Profile }\end{array}$ \\
\hline & 3. Pembajakan Talent oleh IPP & & & V & & V & Strategik Manajemen Talent dan suksesi karier & Perlunya Program Carrier Path dan Manaj Sukse \\
\hline \multirow[t]{2}{*}{ Technological } & 1. Perkembangan Teknologi Informatika dan Digital & & V & & & V & Update teknologi dan kompetensi SDM & Peningkatan Kompetensi SDM thd Tek Baru (IT) \\
\hline & 2. Teknologi Energi baru Terbarukan (EBT) & & V & & V & & Implementasi teknologi EBT dan SmartGrid & \\
\hline \multirow[t]{2}{*}{ Environmental } & 1. Issue lingkungan proper mjd standar baku Projec & & V & & v & & Project berbasis Lingkungan & \\
\hline & 2. Tuntutan lender terhadap isu lingkungan tinggi & & V & & V & & Awarness SDM terhadap lingkungan & Program Internalisasi Budaya Peduli Lingkungan \\
\hline \multirow[t]{4}{*}{ Legal } & 1. Kebijakan Energi Nasional sangat mendukung & & & V & & V & Regulasi yang mendukung Domestik & \\
\hline & 2. Deregulasi pembebasan lahan \& perijinan & & & V & V & & Sebagai payung hukum dan kepastian eksekusi & \\
\hline & 3. Regulasi tentang Ketenagakerjaan & & & V & V & & Jaminan tenaga kerja dan strategi $\mathrm{HCM}$ & $\begin{array}{l}\text { Perlunya Program Engagement dan Retention } \\
\text { dlm Man.HCM }\end{array}$ \\
\hline & 4. Regulasi tentang PMN dari Pemerintah & & & V & V & & Kepastian dan jaminan dalam PMN & \\
\hline
\end{tabular}

\section{Pembahasan}

PLN Organizational Leader sebagai strategi dalam menajemen talent untuk menyiapkan ketersediaan future leader secara kwantitas dan kwalitas sesuai kebutuhan perusahaan[11] dengan melakukan optimalisasi pengelolaan talent yang berorientasi pada prinsip "The right man in the right place" dan "The right man in the right job" [12] maka diperlukan breakthrough sebagai berikut :

1. Membuat Data Talent Profile dengan Profil kepribadian talent

2. Menyusun Profil Karakter Unit Kerja,

3. Manajemen Karir

\subsection{Penyusunan Profil Kepribadian [13]}

1. Pendataan Talent

Sesuai Edaran Direksi No. 007.E/DIR/2015. Masing-masing kandidat talent diberikan penilaian berdasarkan:

a. Riwayat Jabatan (bobot 20\%)

b. Assesmen Kompetensi (bobot 30\%)

c. Assesmen Potensi (bobot 40\%)

d. Hasil Evaluasi (bobot 10\%)

Dari Hasil pendataan diperoleh 52 kandidat talent Manajer Rayon dan 50 Kandidat Talent Asisten Manajer 
2. Pelaksanaan Psikotes

Psikotes dilaksanakan dengan metode: Paper and Pencil Test, Observasi dan Wawancara. Aspek yang diungkap dalam psikotes diantaranya:

a. Aspek Intelektual (tipe Praktis dan tipe teoritis)

b. Profil Kepribadian meliputi Tipologi MBTI, Sikap Kerja, Fleksibilitas perubahan dan adaptasi lingkungan social.[8]

c. Cara Kerja (detail, ketelitian, ketahanan, sistematika kerja)

Psikotes dilaksanakan oleh Lembaga Konsultan Psikologi yaitu PT Karmacon

Tanzil \& Associates) dengan peserta sejumlah 97 pegawai yang masuk dalam talent pool. [14]

\subsection{Penyusunan Karakter Unit [15]}

1. Pendataan data pengusaahan masing-masing Unit kerja (Area \& Rayon)

Data Pengusahaan Unit Kerja yang dihimpun meliputi Data Tanggung jawab unit dan beban kerja (aseet dan pelanggan yang dikelola)

2. Pendataan kondisi geografis, demografi dan budaya masing-masing unit kerja

Pendaataan kondisi geografi, demografi dan budaya dari masing-masing Unit kerja dilakukan dengan metode studi literatur yang dikonfirmasikan kesesuaiannya dengan Unit Kerja terkait.

3. Pengelompokan Unit Kerja berdasarkan karakter

Pengelompokan Unit kerja berdasarkan karakter demografi dan geografis yang dilakukan dengan metode panel expert.

Unit kerja tingkat Area dikelompokkan berdasarkan 3 Cluster yaitu:
a. Metropolis
b. Non Metropolis \& Industri
c. Non Metropolis

\subsection{Pembobotan Cluster Area dan Rayon berdasarkan analisa tantangan eksternal.}

Analisa dilakukan dengan metode panel Expert dan studi literature terhadap faktor-faktor eksternal yaitu; Geografis, Tuntutan Kualitas Layanan, Budaya, Koordinasi dan Komunikasi serta Tantangan Proaktivitas Bisnis (Bussiness Accumen)

\subsection{Implementasi dan Hasil}

Dari realisasi hasil penyusunan profil keperibadian talent, penyusunan karakter unit dalam beberapa kluster dan analisa pembobotan cluster berdasarkan factor-faktor eksternal didapatkan hasil sebagai berikut:

Hasil pembobotan Cluster Area dan Rayon berdasarkan faktor Ekternal dapat dilihat pada table.

Tabel 3. Pembobotan Cluster Area berdasarkan Tantangan Eksternal

\begin{tabular}{|c|l|c|c|c|}
\multirow{2}{*}{ NO } & \multicolumn{1}{|c|}{ FAKTOR } & $\begin{array}{c}\text { METROPOLIS/ } \\
\text { KOTA }\end{array}$ & $\begin{array}{c}\text { NON } \\
\text { METROPOLIS \& } \\
\text { INDUSTRI }\end{array}$ & $\begin{array}{c}\text { NON } \\
\text { METROPOLIS }\end{array}$ \\
\cline { 3 - 5 } & \multicolumn{1}{|c|}{$\mathbf{A}$} & $\mathbf{B}$ & $\mathbf{C}$ \\
\hline 1 & TANTANGAN GEOGRAFIS & $5 \%$ & $5 \%$ & $10 \%$ \\
\hline 2 & TUNTUTAN KUALITAS LAYANAN & $25 \%$ & $30 \%$ & $30 \%$ \\
\hline 3 & TANTANGAN BUDAYA & $10 \%$ & $5 \%$ & $10 \%$ \\
\hline 4 & TANTANGAN KOORDINASI \& KOMUNIKASI & $25 \%$ & $20 \%$ & $30 \%$ \\
\hline 5 & TANTANGAN PROAKTIVITAS BISNIS (BUSSINESS ACCUMEN) & $35 \%$ & $40 \%$ & $20 \%$ \\
\hline & TOTAL & $\mathbf{1 0 0 \%}$ & $\mathbf{1 0 0 \%}$ & $\mathbf{1 0 0 \%}$ \\
\hline
\end{tabular}




\section{KILAT}

Vol. 9, No. 1, April 2020, P-ISSN 2089-1245, E-ISSN 2655-4925

DOI: https://doi.org/10.33322/kilat.v9i1.786

Tabel 4. Pembobotan Cluster Rayon berdasarkan Tantangan Eksternal Unit

\begin{tabular}{|c|c|c|c|c|c|c|c|c|c|}
\hline \multirow{2}{*}{ NO } & \multirow{2}{*}{ FAKTOR } & \multicolumn{2}{|c|}{ METROPOLIS/ KOTA } & \multirow{2}{*}{$\begin{array}{l}\text { IBUKOTA/ } \\
\text { KABUPATEN }\end{array}$} & \multicolumn{2}{|c|}{ INDUSTRI } & \multicolumn{2}{|c|}{ RURAL / KECAMATAN } & \multirow{2}{*}{ PEMBANGKIT } \\
\hline & & A & B & & A & B & A & B & \\
\hline 1 & TANTANGAN GEOGRAFIS & $10 \%$ & $10 \%$ & $10 \%$ & $5 \%$ & $5 \%$ & $25 \%$ & $25 \%$ & $30 \%$ \\
\hline 2 & TUNTUTAN KUALITAS LAYANAN & $30 \%$ & $35 \%$ & $30 \%$ & $35 \%$ & $35 \%$ & $25 \%$ & $25 \%$ & $30 \%$ \\
\hline 3 & TANTANGAN BUDAYA & $10 \%$ & $10 \%$ & $10 \%$ & $10 \%$ & $5 \%$ & $30 \%$ & $30 \%$ & $20 \%$ \\
\hline 4 & TANTANGAN KOORDINASI \& KOMUNIKASI & $25 \%$ & $20 \%$ & $30 \%$ & $20 \%$ & $20 \%$ & $10 \%$ & $10 \%$ & $10 \%$ \\
\hline 5 & TANTANGAN PROAKTIVITAS BISNIS & $25 \%$ & $25 \%$ & $20 \%$ & $30 \%$ & $35 \%$ & $10 \%$ & $10 \%$ & $10 \%$ \\
\hline & TOTAL & $100 \%$ & $100 \%$ & $100 \%$ & $100 \%$ & $100 \%$ & $100 \%$ & $100 \%$ & $100 \%$ \\
\hline
\end{tabular}

Dengan jumlah unit area di Distribusi Jawa Timur sebanyak 16 unit maka hasil Pengelompokkan Area adalah seperti table dibawah ini.

Tabel 5. Pengelompokan Unit Area berdasarkan Karakter Unit

\begin{tabular}{|l|l|l|}
\hline \multicolumn{1}{|c|}{ Metropolis (A) } & \multicolumn{1}{c|}{$\begin{array}{c}\text { Non Metropolis + Industri } \\
\text { (B) }\end{array}$} & \multicolumn{1}{c|}{ Non Metropolis (C) } \\
\hline Area Surabaya Utara & Area Bojoneoro & Area Banyuwangi \\
\hline Area Gresik & Area Mojokerto & Area Jember \\
\hline Area Surabaya Barat & Area Malang & Area Kediri \\
\hline Area Surabaya Selatan & Area Pasuruan & Area Madiun \\
\hline \multicolumn{1}{|c|}{ Metropolis (A) } & $\begin{array}{c}\text { Non Metropolis + Industri } \\
(\text { B })\end{array}$ & \multicolumn{1}{c|}{ Non Metropolis (C) } \\
\hline Area Sidoarjo & & Area Pamekasan \\
\hline & & Area Ponorogo \\
\hline & & Area Situbondo \\
\hline
\end{tabular}


Dalam bentuk matrik profil karakter unit area dan tantangan Eksternal dapat dilihat seperti dalam table dibawah ini.

Tabel 6. Matrik Profil Karakter Unit Area dan Tantangan Ekternal

\begin{tabular}{|c|c|c|c|c|c|c|c|c|}
\hline NO & AREA & CLUSTER & $\begin{array}{l}\text { TANTANGAN } \\
\text { GEOGRAFIS }\end{array}$ & $\begin{array}{c}\text { TUNTUTAN } \\
\text { KUALITAS } \\
\text { LAYANAN }\end{array}$ & $\begin{array}{c}\text { TANTANGAN } \\
\text { BUDAYA }\end{array}$ & $\begin{array}{r}\text { TANTANGAN } \\
\text { KOORDINASI \& } \\
\text { KOMUNIKASI }\end{array}$ & $\begin{array}{c}\text { TANTANGAN } \\
\text { PROAKTIVITAS } \\
\text { BISNIS } \\
\text { (BUSSINESS } \\
\text { ACCUMEN) }\end{array}$ & TOTAL BOBOT \\
\hline 1 & AREA SURABAYA UTARA & METROPOLIS/ KOTA & $5 \%$ & $25 \%$ & $10 \%$ & $25 \%$ & $35 \%$ & $100 \%$ \\
\hline 2 & AREA GRESIK & METROPOLIS/ KOTA & $5 \%$ & $25 \%$ & $10 \%$ & $25 \%$ & $35 \%$ & $100 \%$ \\
\hline 4 & AREA SURABAYA SELATAN & METROPOLIS/ KOTA & $5 \%$ & $25 \%$ & $10 \%$ & $25 \%$ & $35 \%$ & $100 \%$ \\
\hline 5 & AREA SIDOARJO & METROPOLIS/ KOTA & $5 \%$ & $25 \%$ & $10 \%$ & $25 \%$ & $35 \%$ & $100 \%$ \\
\hline 6 & AREA BOJONEORO & NON METROPOLIS \& INDUSTRI & $5 \%$ & $30 \%$ & $5 \%$ & $20 \%$ & $40 \%$ & $100 \%$ \\
\hline 10 & AREA BANYUWANGI & NON METROPOLIS & $10 \%$ & $30 \%$ & $10 \%$ & $30 \%$ & $20 \%$ & $100 \%$ \\
\hline 11 & AREA JEMBER & NON METROPOLIS & $10 \%$ & $30 \%$ & $10 \%$ & $30 \%$ & $20 \%$ & $100 \%$ \\
\hline 12 & AREA KEDIRI & NON METROPOLIS & $10 \%$ & $30 \%$ & $10 \%$ & $30 \%$ & $20 \%$ & $100 \%$ \\
\hline 13 & AREA MADIUN & NON METROPOLIS & $10 \%$ & $30 \%$ & $10 \%$ & $30 \%$ & $20 \%$ & $100 \%$ \\
\hline 14 & AREA PAMEKASAN & NON METROPOLIS & $10 \%$ & $30 \%$ & $10 \%$ & $30 \%$ & $20 \%$ & $100 \%$ \\
\hline 15 & AREA PONOROGO & NON METROPOLIS & $10 \%$ & $30 \%$ & $10 \%$ & $30 \%$ & $20 \%$ & $100 \%$ \\
\hline 16 & AREA SITUBONDO & NON METROPOLIS & $10 \%$ & $30 \%$ & $10 \%$ & $30 \%$ & $20 \%$ & $100 \%$ \\
\hline
\end{tabular}

Untuk matrik profil karakter unit rayon dapat dilihat pada lembar lampiran.

Dari 113 jumlah Unit kerja tingkat Rayon dikelompokkan berdasarkan 8 Cluster yaitu dengan Hasil seperti dalam table. 


\section{KILAT}

Vol. 9, No. 1, April 2020, P-ISSN 2089-1245, E-ISSN 2655-4925

DOI: https://doi.org/10.33322/kilat.v9i1.786

Tabel 7. Pengelompokan Unit Rayon berdasarkan Karakter Unit

\begin{tabular}{|c|c|c|}
\hline No & Cluster & Rayon \\
\hline 1 & $\begin{array}{l}\text { Metropolis / Kota Kecil } \\
\text { (A) }\end{array}$ & $\begin{array}{l}\text { Banyuwangi Kota, Blimbing, Bojonegoro Kota, } \\
\text { Kenjeran, Madiun Kota, Pasuruan Kota, Porong }\end{array}$ \\
\hline 2 & $\begin{array}{l}\text { Metropolis / Kota Besar } \\
\text { (B) }\end{array}$ & $\begin{array}{l}\text { Darmo Permai, Dinoyo, Dukuh Kupang, Embong } \\
\text { Wungu, Indrapura, Jember Kota, Jombang, Kediri Kota, } \\
\text { Malang Kota, Menganti, Mojokerto, Ngagel, Ploso } \\
\text { Surabaya Utara, Sidoarjo Kota, Probolinggo }\end{array}$ \\
\hline No & Cluster & Rayon \\
\hline 3 & Ibukota Kabupaten & $\begin{array}{l}\text { Bangkalan, Batu, Blitar, Bondowoso, Caruban, Kepanjen, } \\
\text { Kraksaan, Lumajang, Magetan, Nganjuk, Ngawi, Pacitan, } \\
\text { Pamekasan, Panarukan, Ponorogo, Sampang, Trenggalek, } \\
\text { Tulungagung, Lamongan, Pare, Bangkalan, Batu, Blitar, } \\
\text { Bondowoso, Caruban, Kepanjen, Kraksaan, Lumajang, } \\
\text { Magetan, Nganjuk, Ngawi, Pacitan, Pamekasan, } \\
\text { Panarukan, Ponorogo, Sampang, Trenggalek, } \\
\text { Tulungagung, Lamongan, Pare }\end{array}$ \\
\hline 4 & Industri Kecil (A) & Karang Pilang, Lawang, Singosari, Sukorejo \\
\hline 5 & Industri Besar (B) & $\begin{array}{l}\text { Perak, Bangil, Gedangan, Giri, Krian, Mojosari, Pandaan, } \\
\text { Rungkut, Taman, Tandes, Tuban }\end{array}$ \\
\hline 6 & $\begin{array}{l}\text { Rural/ Kecamatan Kecil } \\
\text { (A) }\end{array}$ & $\begin{array}{l}\text { Asembagus, Ambulu, Ambunten, Balong, Besuki, Blega, } \\
\text { Campurdarat, Dampit, Dolopo, Jajag, Kalisat, Kamal, } \\
\text { Kencong, Ketapang, Klakah, Mantingan, Maospati, } \\
\text { Ngantang, Ngunut, Pacet, Padangan, Prenduan, Prigen, } \\
\text { Rambipuji, Sumber Pucung, Srengat, Sumberrejo, } \\
\text { Sutojayan, Tanggul, Tempeh, Tumpang, Waru, } \\
\text { Warujayeng, Wlingi, Wonosari, Bululawang }\end{array}$ \\
\hline 7 & $\begin{array}{l}\text { Rural / Kecamatan Besar } \\
\text { (B) }\end{array}$ & $\begin{array}{l}\text { Babat, Benjeng, Brondong, Genteng, Gondang Legi, } \\
\text { Gondang Wetan, Grati, Grogol, Jatirogo, Kertosono, } \\
\text { Mojoagung, Muncar, Ngadiluwih, Ploso Mojokerto, } \\
\text { Sidayu, Rogojampi, Kebonagung, Ngoro }\end{array}$ \\
\hline 8 & Kepulauan dg Pembangkit & Bawean, Sumenep \\
\hline
\end{tabular}

Dalam melengkapi daftar talent pool dengan melakukan implementasi program breaktrough tersebut pada awal tahun 2016 didapatkan jumlah kandidat yang telah dimaping kepribadian untuk level supervisor atas jabatan manajer rayon sebanyak 49 orang atau $54 \%$ dari talent, untuk jabatan Asisten Manajer area sebanyak 48 orang atau $67 \%$ dari talent yang tersedia. Untuk level manajer dasar jabatan Deputy Manager dan Manajer Area sebanyak 43 orang atau 100\% dari talent yang tersedia. 


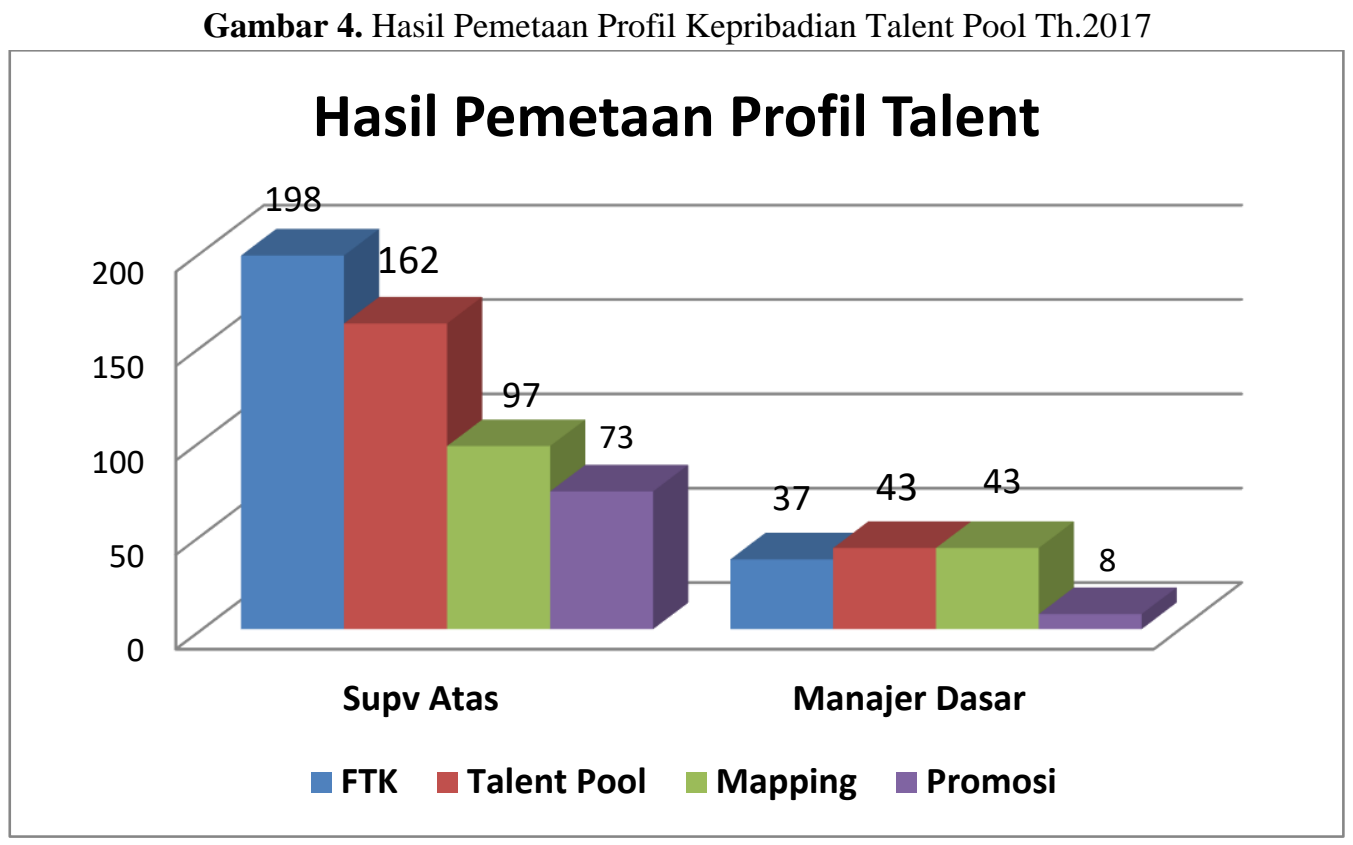

Dengan posisi-posisi kunci di PLN Distribusi Jawa Timur diisi oleh talent yang telah dilakukan maping profil kepribadian dan penempatan promosi sesuai dengan karakter unit didapatkan kinerja PLN Distribusi Jawa Timur meningkat lebih baik $(94,1)$. Peningkatan kualitas dan keandalan ketenagalistrikan dengan operasional yang lebih baik dengan dipilihnya sebagai unit yang disurvey oleh World Bank dalam menentukan ranking Easy Doing of Business khususnya kriteria getting of electricity (Jakarta dan Surabaya).

\section{Kesimpulan}

Dari penelitian ini dalam rangka efektifitas implementasi program pembinaan talent dapat disimpulkan sebagai berikut,

Karakter pribadi talent sudah dilakukan terhadap 140 pegawai atau sebesar $68 \%$ dari talent pool, Model Karakter Unit kerja sudah dapat diklasifikasikan dari tantangan eksternal di unit kerja meliputi; kondisi geografis, budaya, kualitas layanan, komunikasi dan koordinasi serta tantangan Proaktivitas Bisnis (Business Accumen) terhadap program 35000 MW.

Implementasi program project assessment telah menghasilkan kenaikan produktivitas pegawai dengan ditunjukan peningkatan kinerja perusahaan dimana PLN Distribusi Jawa Timur mencapai kinerja terbaik $(94,1)$ untuk distribusi dan wilayah pada semester 2 tahun 2016 dan Nilai NKO 95,0 pada Semester 1 tahun 2017. [16]

Menghasilkan future leader sebanyak $25 \%$ dari total pegawai yang memahami potensi dan tantangan bisnis dengan pertumbuhan ekonomi dan lingkungan bisnis yang berubah cepat sehingga pemetaan karakter personal, karakter unit dan karakter bisnis sangat dibutuhkan untuk menjadikan PLN sebagai Organizational Leaders melalui program pengembangan leadership berdasarkan Karakter Personal dan Karakter Bisnis (Bussiness Accumen) [17]

\section{DAFTAR PUSTAKA}

[1] R. direksi PLN, “Asset Liability Committee ( ALCO ) Des 2018," RAPAT Direksi PLN, no. Des, 2018.

[2] M. Bond, "The makings of great leaders," Nature, 2010. 


\section{KILAT}

Vol. 9, No. 1, April 2020, P-ISSN 2089-1245, E-ISSN 2655-4925

DOI: https://doi.org/10.33322/kilat.v9i1.786

[3] G. Carter, "The war for talent," Australas. Biotechnol., 2011.

[4] E. Direksi, "Direktory kompetensi PLN edisi Vii 2018," DIrKom, vol. 53, no. 9, pp. 16891699, 2018.

[5] F. D. Frank and C. R. Taylor, "Talent Management : Trends that Will Shape the Future," Hum. Resour. Plan., 2004.

[6] J. Moczydłowska, "Talent Management: Theory and Practice of Management. The Polish Experience.," Int. J. Bus. Manag. Econ. Res., 2012.

[7] A. Tyagi, "Personality Profiles Identification Using MBTI Test for Management Students: An Empirical Study," J. Indian Acad. Appl. Psychol., 2008.

[8] V. R. Montequín, J. Villanueva Balsera, J. M. Mesa Fernández, and A. G. Nieto, "Using Myers-Briggs Type Indicator (MBTI) as a Tool for Setting up Student Teams for Information Technology Projects," J. Inf. Technol. Appl. Educ. JITAE, 2012.

[9] D. Gibson, Ivancevich, Organisasi dan Manajemen : Perilaku, Struktur dan Proses. 2010.

[10] M. Planellas and A. Muni, "PESTEL Analysis," in Strategic Decisions, 2019.

[11] C. L. Pearce, "The future of leadership: Combining vertical and shared leadership to transform knowledge work," Academy of Management Executive. 2004.

[12] C. N. Teulings and P. A. Gautier, "The right man for the job," Rev. Econ. Stud., 2004.

[13] S. T. Hannah and B. J. Avolio, "The locus of leader character," Leadership Quarterly. 2011.

[14] J. Fertig and C. Milewicz, "Enhancing classroom performance with the DISC personality profile," Mark. Manag. Assoc. Educ. Conf., 2016.

[15] J. P. Antony and S. Bhattacharyya, "Measuring organizational performance and organizational excellence of SMEs - Part 1: A conceptual framework," Meas. Bus. Excell., 2010.

[16] Kinerja NKO Unit Bisnis dan Formula, "Edaran Direksi 003,E-Dir PLN 2016," 2016.

[17] M. W. Grojean, C. J. Resick, M. W. Dickson, and D. B. Smith, "Leaders, values, and organizational climate: Examining leadership strategies for establishing an organizational climate regarding ethics," Journal of Business Ethics. 2004. 